\title{
BRAIN TOPOGRAPHY OF EMF-INDUCED EEG-CHANGES IN RESTFUL WAKEFULNESS: TRACING CURRENT EFFECTS, TARGETING FUTURE PROSPECTS
}

\section{Biljana Gjoneska ${ }^{1}$, Simona Markovska-Simoska ${ }^{1}$, Hiie Hinrikus ${ }^{2}$, Nada Pop-Jordanova ${ }^{1}$, Jordan Pop-Jordanov ${ }^{1}$}

${ }^{1}$ Macedonian Academy of Sciences and Arts, Skopje, R. Macedonia

${ }^{2}$ Department of Biomedical Engineering, Tallinn University of Technology, Tallinn, Estonia

Corresponding Author: Biljana Gjoneska, Institution: Macedonian Academy of Sciences and Arts, Address: "Krste Misirkov" No. 2, P.O. Box. 428, 1000 Skopje, R. Macedonia, Tel: +38970640913, Email: biljanagjoneska@manu.edu.mk

\begin{abstract}
Introduction: Covering a handful of decades but spanning across two centuries, mobile phones announced the dawn of the technological revolution, standing at the forefront as its' most prominent symbol. Over the course of their sovereign dominance, human generations born with the birth of the mobile phone reached the age of maturity, while scientific community started reaching for experience-based perceptivity.

Aim: The following review serves as a short-cut across a half-decade old research gap, and a clearcut analysis on the cutting-edge knowledge of the EMF induced EEG changes.

Material and Methods: The selection covers 28 articles about mobile phone effects on resting wakeful EEG in humans conducted over the last two decades, across three continents and 12 countries, of which $75 \%$ had positive findings.

Conclusions: At present, the general protocol of a typical study includes investigations on adults (20-60 yrs) grouped in smaller samples and exposed to shorter intervals of GSM-like pulse-modulated signal (10-30 subjects/minutes). The assessment usually involves linear methods for quantitative analysis, while the results mostly revolve around posterior increase in alpha and beta frequency range. The qualitative variations, however, remain open to interpretation. Future research may benefit from multiplication of sub-specific studies leading to replication of more consistent results. The long-term and large-size epidemiologic studies, stratified by age and gender, may also improve the expected outcomes. Regarding the interpretation, non-linear methods could be employed for assessment of individual variations. The emphasis should be placed on theories/measures for better understanding of the subtle interplay between the spectral individualities and mobile phone radiation specifics.
\end{abstract}

Key words: Mobile phones; electromagnetic fields; pulse-modulated and continuous-wave signal; human wake resting electroencephalogram

\section{Introduction}

Radio-frequency (RF) and extremely-low frequency (ELF) electromagnetic fields (EMF) are emitted by a second generation of global systems for mobile communication (GSM), the next generation of universal mobile telecom- munication systems (UMTS), and the latest generation of long-term evolution (LTE) standard devices, all of them known as mobile phones (MP). They stand out as the most prominent EMF sources because they are perpetually used at close proximity to the head, and their effects 
on the electroencephalographic (EEG) features of the central nervous system (CNS) prove to be complex and rather complicated [Kwon and Hämäläinen, 2011; Marino and Carrubba, 2009; van Rongen et al., 2009; Valentini et al., 2007]. Continuing the coded thread of expressing in acronyms and abbreviations, one could say that it remains unclear whether mobile phones will be marked as attention-grabbing headlines (SOS), or attention-seeking punch lines (PS) in the story of our lives (CV's).

In this context, the following statement seems straight-forward but true: Mobile phones quite easily entered our daily lives, penetrating deep into our routines and habits.

Yet, even a statement looking fast-forward into the future, also holds the truth: Mobile phones will hardly exit our lives, surfacing out of our everyday activities as superficial and trivial for our bodies and minds. Not any day soon, it seems.

Indeed, mobile phones are here to stay and they will have their say, if only for awhile. Covering a handful of decades, but spanning across centuries, millennia, even two different eras, they marked the dawn of the scientific, information and technological revolution, as its enduring symbol. Indeed, human generations born with the birth of the mobile phone are already reaching the age of maturity, so the knowledge regarding these technologies is maturing as well, and reaching for deeper levels of meaningful insights. Thus far, the accumulated empirical evidence clearly suggests that MPEMF could potentially influence electrophysiological properties of our brains. But it takes theoretical prowess to turn empirical evidence into credence, and to decrease the level of uncertainty along the "could-would-should" axis by trying to answer three questions:

- How could mobile phones affect our brains (e.g. through which mechanisms)?

- When would mobile phones affect our brains (e.g. under which circumstances)?

- What should happen after (e.g. what are the consequences)?

The following review is born as a followup of the research activities carried within the FP6 Project "Upgrading the Research Capacities for Safety and Health Effects of Human Exposure to Electromagnetic Fields" [SAFEEMF, 2007] and the COST Action "Emerging
EMF Technologies and Health Risk Management" [COST BM0704, 2008]. It is an attempt to cover the shortest distance from the obsolete "could-would-should" to the concrete "canwill-shall" stance, in a concise manner. Moreover, the clear-cut analysis will also serve as a short-cut across the research gap persisting for nearly half a decade, and constantly widening by the lack of summarized knowledge on the topic of interest. Indeed, the latest reviews in this field were published in the first half of the last decade (2007-2011), despite the fact that all of them were alerting for the need of further explorations [Kwon and Hämäläinen, 2011; Marino and Carrubba, 2009; van Rongen et al., 2009; Valentini et al., 2007]. Those reviews were part of a larger group that covered vast area of biological effects from EMF fields [Juutilainen et al., 2011; Vijayalaxmi and Scarfi, 2014], specific for their focus on our field of interest exclusively. Namely they were oriented toward investigation of potential EMF-EEG relationship from sleep to wakefulness, and from resting state to cognitive engagement. Within the integral reviews, the selections of studies on wakeful resting EEG were in good coordination (citing similar sources), and the sections with the findings were in good concordance (referring to the same evidence). Namely, three out of four reviews confirmed that three-quarters of the assessed studies declare significant EEG-change under MP-EMF influence (Fig. 1). The interpretations, on the other hand, ranged from speculations regarding the real presence of the effect, to suspicions regarding the absence of methodological consistencies, but again, recommendations for continual exploring and constant monitoring always remained. As opposed to the decrease in the evaluation reports, the number of experimental studies has increased over the years, yielding a need for revisiting of the field and revising of the findings. More importantly, the number of studies with narrow focus of investigation has reached critical level, suitable for fine-grained analysis. This came as a great convenience, since the delicate nature of the EEG-signal is sensitive to subtlest of changes, so tightening the scope over sub-specific studies with highly standardized protocols seems crucial when referring to uniform comparisons and inferring unified conclusions. Thus we decided to focus on the studies with strict inclusion and exclusion criteria. 


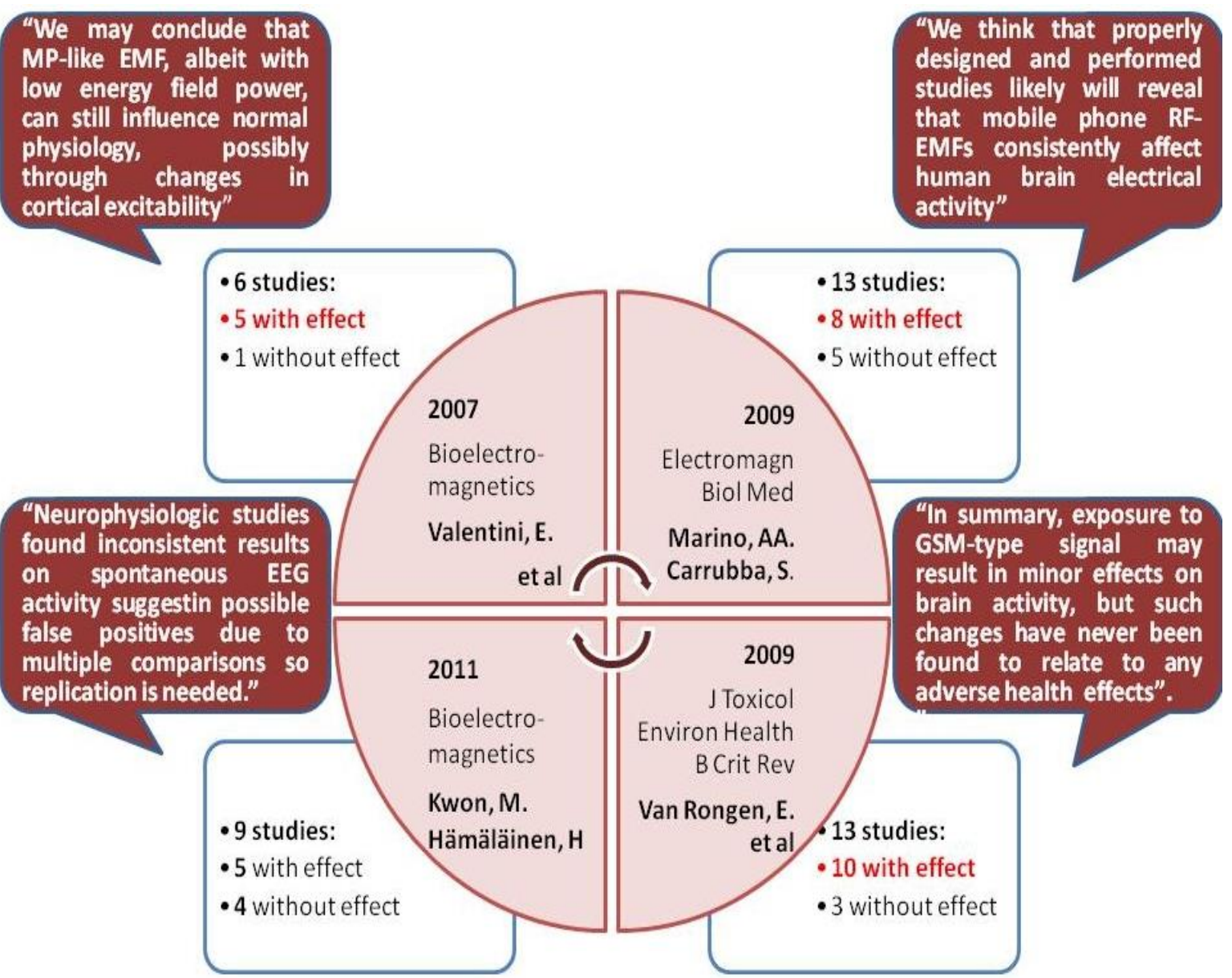

Figure 1 - Overview of recent reviews on EMF-EEG in wakeful restfulness

\section{Material and methods}

Following the "weight of scientific evidence" approach based upon the quality of published studies, we only considered works carried according to high-level standards and good laboratory practices.

All of the selected studies included the listed criteria as a whole:

1. Regarding the participants - only investigations on healthy human population were considered regardless of the age (children, adolescents, adults and elderly subjects).

2. Regarding the protocols - only investigations during wakeful restfulness were taken in consideration regardless of the eye position (opened or closed).

As for the exclusion criteria, special emphasis was placed on the following notions:

1. Regarding the participants - the size of the sample (where studies with less than ten subjects were rejected for further consideration), and the health status of the participants (where presence of various brain pathologies was also subject to rejection).

2. Regarding the protocols - control over the conditions (where randomized, singleblinded studies were taken as minimum criteria for inclusion), and the design (where crossover procedure was taken as obligatory standard).

3. Regarding the methodology - noise control (with proper statement regarding the artifact rejection) and EMF source control (with detailed elaboration on the used equipment).

Once the coordinates were established, a two-step selection process was conducted:

1. Coarse-grained exploratory analysis in the most comprehensive scientific databases (PubMed, WorldCat and Google Scholar) where the keywords "mobile phone", "cellular phone", "electromagnetic field" along with their associated acronyms were combined with several words describing the outcome of interest: "electroencephalogram", "brain physiology", "wake" and "rest". 
2. Fine-grained analysis over selected articles in order to subselect those which were published in international peer-reviewed journals (as registered in SCImago portal for journal and country ranking, as well as the Web of Science and Scopus Databases).

Once the final selection was conducted, the search for remaining articles was performed as an additional control in the following way: over-viewing the cited references base of selected articles, as well as the articles that referenced them (with the help of the citations section in PubMed and Google Scholar).

The final selection comprised of 28 studies conducted over two decades (1995-2015), across three continents (Europe, Asia and Aus- tralia) and 12 countries (Australia, China, Estonia, France, Finland, Germany, Greece, Hungary, Italy, Malaysia, Switzerland and Ukraine). Of the total, 25 fitted well with the required criteria, and three had some uncertainties (such as poor description of the used methodology and protocols, short exposure time and small sample size). However, they are included in the final list and taken in consideration upon the subsequent analysis. Some studies included two or more separate investigations (with separate samples and/or specific custom-tailored protocols for each group), so their findings were treated as independent results within the summary section (Tab. 1).

Table 1

Overview of studies exploring the EMF from standardized sources (model handset, dipole or quarter-wave antenna and, exceptionally, commercial phones) on wakeful resting EEG (1995-2015)

\begin{tabular}{|c|c|c|c|c|c|c|c|c|c|}
\hline Author(s) & $\begin{array}{l}\text { Journal } \\
\text { (Abbreviation) }\end{array}$ & Year & $\begin{array}{c}\text { Sum Effect } \\
\text { (1=Yes) }\end{array}$ & $\begin{array}{c}\text { Exposure } \\
\text { (Min) }\end{array}$ & $\begin{array}{c}\text { Subjects } \\
\text { (No) }\end{array}$ & $\begin{array}{l}\text { Group } \\
\text { (Age) }\end{array}$ & $\begin{array}{l}\text { Expos. } \\
\text { Side }\end{array}$ & $\begin{array}{c}\text { Mobile } \\
\text { Equipement }\end{array}$ & $\begin{array}{c}\text { Radio } \\
\text { Frequency }\end{array}$ \\
\hline Ghosn, R., et al. & J Neurophysiol & 2015 & 1 & 15 & 26 & Adults & L & GSM-like & $900 \mathrm{MHz}$ \\
\hline Lv, B., et al. & Conf Proc IEEE Eng Med Biol Soc & 2014 & 1 & 30 & 10 & Adults & $R$ & LTE-like & $2.573 \mathrm{GHz}$ \\
\hline Bachmann, M., et al. & P Est Acad Sci & 2014 & 1 & 10 & 14 & Adults & $\mathrm{L}$ & GSM-like & $450 \mathrm{MHz}$ \\
\hline Perentos, N., et al & IEEE Trans Biomed Eng & 2013 & 1 & 20 & 72 & Adults & $R$ & GSM-like & $900 \mathrm{MHz} / \mathrm{PM}$ modul \\
\hline Trunk, A., et al. & Bioelectromagnetics & 2013 & 0 & 30 & 17 & Adults & $R$ & UMTS-like & $1947 \mathrm{MHz}$ \\
\hline Loughran, S. P., et al & Clin Neurophysiol & 2013 & 0 & 30 & 22 & Adolescents & $\mathrm{L}$ & GSM-like & $900 \mathrm{MHz}$ \\
\hline Suhhova, A., et al. & Bioelectromagnetics & 2013 & 1 & 10 & 15 & Adults & $\mathrm{L}$ & GSM-like & $450 \mathrm{MHz}$ \\
\hline \multirow{2}{*}{ Hinrikus, H., at al. } & \multirow{2}{*}{ Int J Radiat Biol } & \multirow{2}{*}{2011} & 1 & 30 & 14 & Adults & L & GSM-like & $450 \mathrm{MHz}$ \\
\hline & & & 1 & 10 & 14 & Adults & L & GSM-like & $450 \mathrm{MHz}$ \\
\hline \multirow{3}{*}{ Croft, R. J., et al. } & \multirow{3}{*}{ Bioelectromagnetics } & \multirow{3}{*}{2010} & 0 & 55 & 41 & Adolescents & $R / L$ & GSM-like & $894.6 \mathrm{MHz}$ \\
\hline & & & 1 & 55 & 42 & Adults & $R / L$ & GSM-like & $894.6 \mathrm{MHz}$ \\
\hline & & & 0 & 55 & 20 & Elderly & $R / L$ & GSM-like & $894.6 \mathrm{MHz}$ \\
\hline Vecchio, F., et al. & Clin Neurophysiol & 2010 & 1 & 45 & 16 & Elderly & L & GSM-like & $902.4 \mathrm{MHz}$ \\
\hline Croft, R. J., et al. & Bioelectromagnetics & 2008 & 1 & 30 & 120 & Adults & $R / L$ & GSM-like & $894.6 \mathrm{MHz}$ \\
\hline Kleinlogel, $\mathrm{H}_{.}$, et al & Bioelectromagnetics & 2008 & 0 & 30 & 15 & Adults & L & UMTS-like & $1950 \mathrm{MHz}$ \\
\hline \multirow{4}{*}{ Hinrikus, $\mathrm{H}_{\text {., }}$ at al. } & \multirow{4}{*}{ Bioelectromagnetics } & \multirow{4}{*}{2008} & 1 & 10 & 19 & Adults & L & GSM-like & $450 \mathrm{MHz} / 7 \mathrm{~Hz} \mathrm{PM}$ \\
\hline & & & 1 & 10 & 13 & Adults & $\mathrm{L}$ & GSM-like & $450 \mathrm{MHz} / 14 \& 21 \mathrm{PM}$ \\
\hline & & & 1 & 10 & 15 & Adults & L & GSM-like & $450 \mathrm{MHz} / 40 \& 70 \mathrm{PM}$ \\
\hline & & & 0 & 10 & 15 & Adults & L & GSM-like & $450 \mathrm{MHz} / 217 \mathrm{~Hz}^{*} 1 \mathrm{MHz}$ \\
\hline \multirow{2}{*}{ Hountala, C. D., et al } & \multirow{2}{*}{ Neurosci Lett } & \multirow{2}{*}{2008} & 1 & 45 & 19 & \multirow{2}{*}{ Adults } & $R$ & GSM-like & $900 \mathrm{MHz}$ \\
\hline & & & 1 & 45 & 20 & & $R$ & UMTS-like & $1800 \mathrm{MHz}$ \\
\hline Hinrikus, H., at al. & Int J Radiat Biol & 2008 & 1 & 10 & 13 & Adults & L & GSM-like & $450 \mathrm{MHz}$ \\
\hline Vecchio, F., et al. & Eur J Neurosci & 2007 & 1 & 45 & 10 & Adult & $\mathrm{L}$ & GSM-like & $902.4 \mathrm{MHz}$ \\
\hline Regel, S. J., et al. & Neuroreport & 2007 & 1 & 30 & 24 & Adults & $\mathrm{L}$ & GSM-like & $900 \mathrm{MHz}$ \\
\hline Perentos, N., et al. & Australas Phys Eng Sci Med & 2007 & 0 & 15 & 12 & Adults & L & GSM-like & $900 \mathrm{MHz}$ \\
\hline Curcio, G., et al. & Neurosci Res & 2005 & 1 & 45 & 20 & Adults & L & GSM-like & $902.4 \mathrm{MHz}$ \\
\hline Hinrikus, $\mathrm{H}_{.}$, at al. & Bioelectromagnetics & 2004 & 0 & 11 & 20 & Adults & L & GSM-like & $450 \mathrm{MHz}$ \\
\hline D'Costa, H., et al. & Australas Phys Eng Sci Med & 2003 & 1 & 25 & 10 & Adults & Behind & GSM-like & $900 \mathrm{MHz}$ \\
\hline Huber, R., et al. & J Sleep Res & 2002 & 1 & 30 & 16 & Adults & $\mathrm{L}$ & GSM-like & $900 \mathrm{MHz}$ \\
\hline Hietanen, M., et al. & Scand J Work Environ Health & 2000 & 0 & 20 & 19 & Adults & $R / L$ & GSM-like & $900 \mathrm{MHz}$ \\
\hline Roeschke, J., \& Klaus, M. & Bioelectromagnetics & 1997 & 0 & 3.5 & 34 & Adults & $\mathrm{L}$ & GSM-like & $900 \mathrm{MHz}$ \\
\hline Reiser, H., et al. & Eur J Med Res & 1995 & 1 & 15 & 36 & Adults & Behind & GSM-like & $902.4 \mathrm{MHz}$ \\
\hline \multirow{2}{*}{\multicolumn{2}{|c|}{ Kramarenko, A. V., \& Unel Int J Neurosci }} & & 1 & 0.33 & 10 & Adults & & \multirow{2}{*}{ GSM-like } & \multirow[b]{2}{*}{$900 \mathrm{MHz}$} \\
\hline & & 2003 & 1 & 0.33 & 10 & Children & & & \\
\hline Murat, Z. Hj, et al. & Int J Simul Syst Sci Technol & 2011 & 1 & 5 & 30 & Adults & $R / L$ & & \\
\hline Isa, R. M., et al. & Procedia Soc Behav Sci & 2013 & 1 & 5 & 95 & Adults & $R / L$ & & \\
\hline
\end{tabular}

*Marked with yellow are studies with uncertainties in the selection criteria. Studies with several separate finding are noted accordingly 


\section{Results}

Participants and Protocols: The general tendency toward employment of a pragmatic strategy was evident on an international scale (Fig. 2). Therefore, various national laboratories opted for smaller sample size and shorter periods of EMF exposure with the predominant size/time ranging between 10 and 30 subjects/minutes. An exceptional case was the study conducted by Croft and colleagues on a batch of 120 participants, stratified by age along with two more recent ones all of them with positive evidence as to the existence of the EMF-induced EEG-effect [Croft et al., 2008; Isa et al., 2013; Perentos et al., 2013]. Even though practical solution seems reasonable and effective, especially when accumulated in the bulk with other experimental evidence, the investment in larger epidemiological longitudinal studies should be given credit as well. The indicators that such study would yield more comprehensive information and shed new light on this problem, seem scarce but promising.

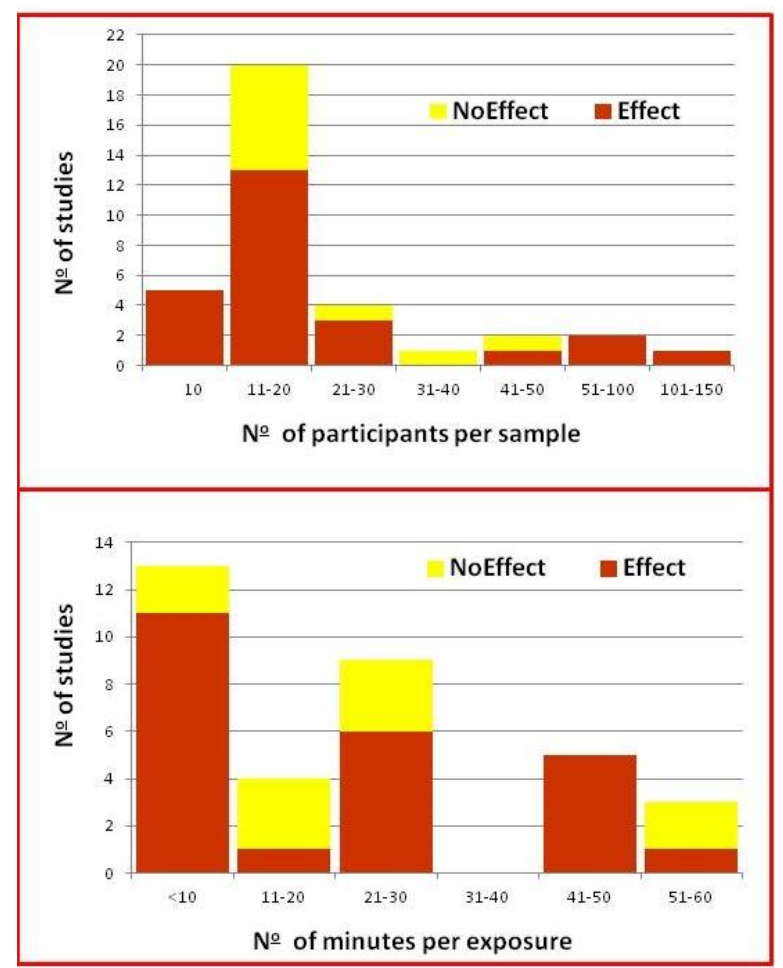

Figure 2 - Histograms of studies grouped by the sample size and time of exposure

Due to the possible ethical constrictions tied closely with potential public-health restrictions regarding the suggested age-range for scientific exploration, it seems reasonable that most of the laboratories decided to opt for precautionary politics and focus on the adult population (ranging between 20 and 60 years). This can be viewed in positive light, since it adds to the homogeneity of the groups, and to the certainty of the results as a whole. Only two studies dealt with groups of adolescents (13-19 years), failing to reject the null hypothesis [Croft et al., 2008; Loughran et al., 2013]. Another couple of experiments that were performed in similar periods by different laboratories included groups of elderly subjects (6080 years) with mixed results [Croft et al., 2008; Vecchio et al., 2010]. Namely Croft's group failed to find any effect on the power spectral analysis in the alpha frequency band caused by the second and third generation mobile phones, whereas Vecchio's group found increased inter-hemispheric coherence in alpha band at both, frontal and temporal regions, during exposure. A single study was performed on a small group of children (12 years) witnessing appearance of slow-wave activity on the frontal and temporal region contra-lateral to the side of exposure [Kramarenko and Tan, 2003]. As an exception with regards to the registered results and chosen population, this study only serves to caution that special considerations should be made when deciding to venture into an exploration that includes children.

Separate mention should be given to a study with a separate research interest, oriented toward gender differences in relation to 900/1800 MHz signal [Hountala et al., 2008]. Namely, an inverse reaction was registered under the influence of $1800 \mathrm{MHz}$ field, with decreased inter-hemispheric coherence for males, and increased for females. In addition, females demonstrated the same trend for 900 $\mathrm{MHz}$ signal as well, while males did not replicate the previous result. Hence, the gender issue remains unresolved, especially when different physiology is taken in consideration.

Methodology of work: Only studies with clear specifications regarding the implemented technology were chosen for evaluation. In summary, experimenters used several standardized EMF-sources: model handset, dipole or quarter-wave antenna and, exceptionally, commercial phones. The equipment was usually placed 
on one side of the head (predominantly near the left ear, with rare cases of occipital positioning) on a varying distance (usually 2, 10 or $40 \mathrm{~cm}$ ). Most of the studies employed GSM-like technology, whereas the studies incorporating the newer generations were sporadic and conflicting in their outcomes, thus inconclusive. The cumulative report of the findings as a whole is illustrated accordingly, confirming the results from all preceding meta-analyses (Fig. 3). Similarly, a rough estimate of three-quarters from all EEG experiments, were marked by a noticeable change (in 26 out of 36 groups for investigation). Of those, again three-quarters were in the alpha-frequency band, followed by changes in beta, delta and theta domain, while no effect was ever registered in the gamma band.

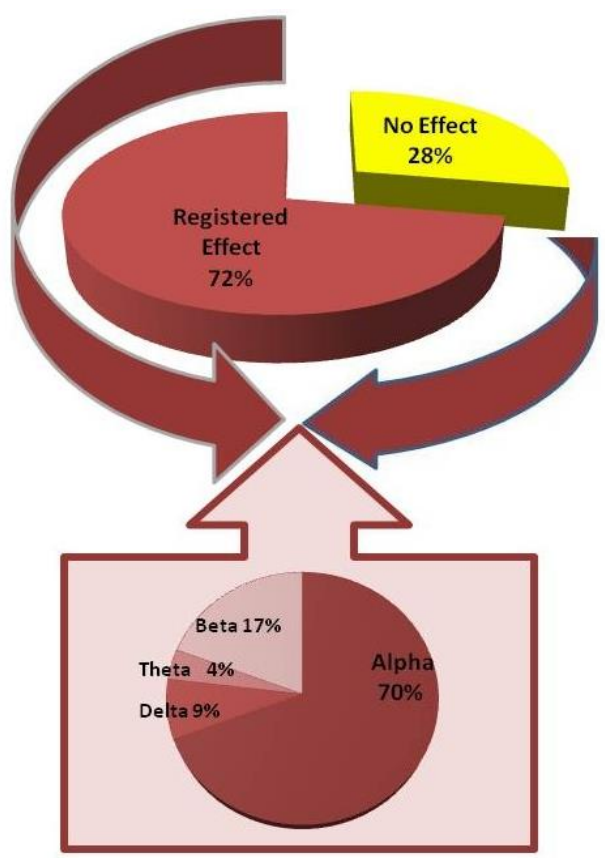

Figure 3 -Cumulative illustration on the EMF-induced EEG-effect

Regarding the emitted EMF, nine studies made attempt at distinguishing the influence between continuous wave and pulse modulated signal [Bachmann et al., 2014; Hinrikus et al., 2004; Hinrikus et al., 2008a; Hinrikus et al., 2011; Huber et al., 2002; Perentos et al., 2007; Perentos et al., 2013; Regel et al., 2007]. After excluding couple of studies [Hinrikus et al., 2004; Perentos et al., 2007] the remaining majority confirmed significant PM-EMF influence, although with varying and inconsistent results (mostly effective at 2, 7, 40 and $70 \mathrm{~Hz}$ modulation). On the contrary, if we exempt a single study [Perentos et al., 2013] the rest of the findings did not demonstrate any effect from non-modulated CW-EMF. More elaborately, the resulting EEG-signal seemed unchanged before and after the EMF-exposure, as if undisturbed by the $\mathrm{CW}$ signal.

Special mention should be given to the Estonian research group for trying to disentangle the weight of influence coming from various factors in the EMF-source setting. This was done by deconstructing the applied methodology in series of sequential experiments at $450 \mathrm{MHz}$ consisting of: application of PM at a different frequency on a single group of subjects at separate time-intervals [Hinrikus et al., 2008b], application of different PM-EMF on separate groups [Hinrikus et al., 2008a; Hinrikus et al., 2011], and application of EMF with different specific absorption rates [Suhhova et al., 2013].

Analysis: Overall, the objective of a typical study is oriented toward the assessment of the EMF-influence on the power of resting EEG rhythms. Therefore, the analysis consists of processing raw EEG-signal to get the timefrequency domain. Fast Fourier Transformation (FFT) is used as standard operation to get Power Spectrum Density (PSD) for each frequency band in the EEG time-series data. The brain topography of the cumulative findings regarding PSD (where information for spatial distribution was available) is illustrated as follows (Fig. 4).

As evident, studies registering increase in alpha-frequency domain mostly reported changes in the frontal and temporo-occipital region, whereas studies registering decrease in the same domain reported changes along frontal and central regions of the brain.

The small sample from the vast majority of studies was however, concerned with the EMF-influence over the functional coupling of cerebral rhythms, which roughly reflects the operative binding between coupled brain regions and relative information transfer. Linear components of that coupling are nicely modeled with inter-hemispheric spectral coherence of the EEG rhythms, and presented as general (de)synchronization under EMF exposure. 


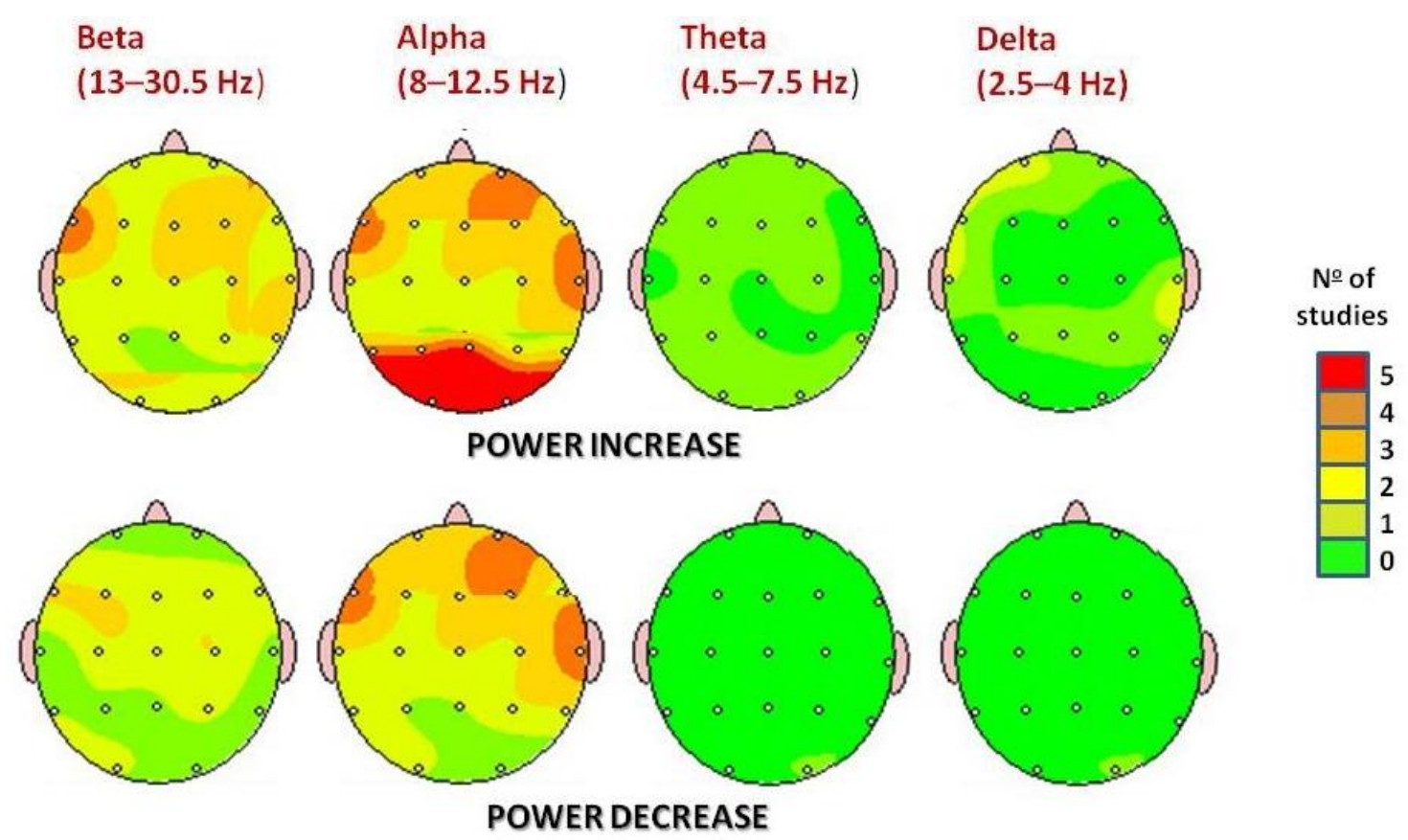

Figure 4 - The brain topography of the cumulative findings regarding power spectrum density distribution under the exposure of EMF from mobile phones

The smallest group of incidental studies dared to venture into non-linear methods for component-analysis, stating that EEG-signal itself is non-linear, non-stationary and noisy. Hence the applied analysis should be adequate. Some suggested that this type of analysis seems suitable for consideration of individual variations in each subject, independently from the group. At present there is lack of consensus as to the most representative (i.e. sensitive and specific) non-linear analysis method, but the promising perspectives should be kept in mind for future plans.

\section{Discussion}

Folded within the repetitive finding associated with changes in the alpha-frequency domain, there is another repetition: namely there is a consistent finding of inconsistencies between individuals. Indeed, the general pattern of change cannot be further explored with more specific method, nor explained in more detailed manner, as already noticed and reported on several occasions.

In their study, Croft and colleagues mention that "the main effect of exposure during the active period showed an alpha increase only in $60 \%$, suggesting that the effect of the phone was not homogeneous and that it may be rela- ted to individual differences between the participants" [Croft et al., 2008]. Loughran and his team adhered to the same conclusion referring that "as cited literature demonstrates, the most consistent effect observed is a change in the alpha band power. However, these changes sometimes correspond to an increase in the alpha power, and sometimes to a decrease. The reason why alpha band power reacts differently to the RF exposure remains unclear. The main problem lies in the use of different methods, different experimental protocols and/or different intensities or frequencies, thus making the comparison of data more difficult. Also, individual variability is one of the important factors that may explain the discrepancies between the results" [Loughran et al., 2013]. Hinrikus with her collaborators provide triple-confirmation associating the findings to their own hypothesis that "the effect of microwave exposure differs for individuals; some of the subjects under investigation may be significantly affected and others not. Therefore, the effect of microwave exposure appears to be not statistically significant for the whole group, but it can be significant for some individuals" [Hinrikus et al., 2008a]. Finally, the most recent study by Perentos at al. reports that "the direction of the change was not consistent with the majority of 
the literature, but is consistent with the view that the RF effect on the EEG is an indirect response to exposure rather than being a direct result of it" [Perentos et al., 2013].

In quest for answers, in their review Juutilainen's group suggests that one should consider the key question of "whether the effects observed indeed reflect interaction of modulated signals with the complex structure and function of the nervous system (which itself generates electrical signals with frequencies close to the modulation frequencies used in experimental studies on bioeffects of RF fields)" [Juutilainen et al., 2011]. The experimental results reported by Hinrikus' team answer the question how "the proposed model of parametric excitation of brain oscillations, based on polarization of water molecules, qualitatively explains the nature of the effect of modulated microwave radiation on the EEG rhythms" [Hinrikus et al., 2011]. In addition, Pop-Jordanovs states that the underlying mechanism of many reported individual variations results from the "subtle interplay between the spectral individualities and radiation specifics" [Pop-Jordanov and Pop-Jordanova, 2011] while Challis titles the phenomenon as "neural interference" [Croft et al., 2008].

In the light of the aforementioned interpretations, the following addition may be viewed as an extension to the mentioned line of reasoning on this topic. Namely, the notion that mobile phones could act as uncontrolled neurofeedback modulators could be taken for future serious considerations. Thus, a simple measure of the mental arousal, such as EEG-spectrum weighted frequency (brain-rate), can serve as useful preliminary indicator of the MP influence and a training parameter as well [PopJordanova and Pop-Jordanov, 2005].

\section{Conclusion}

This review covers selection of 28 articles consisting of 36 separate experiments about MP-EMF effects on resting wakeful EEG in humans, conducted within the period of the last 20 years, across 3 continents and 12 countries, of which $75 \%$ confirmed the existence of EMFEEG relationship.

At present, the general protocol of a typical study includes: predominant investigation of adults (20-60 years) grouped in smaller sample sizes and exposed for shorter intervals (10-30 subjects/minutes) to GSM-like pulsemodulated signal. The post-hoc analysis usually revolves around linear methods of assessment, while the qualitative results mostly involve increase in alpha and beta frequency range. The qualitative variations, however, remain open to interpretation.

Future research may benefit from multiplication of sub-specific studies leading to replication of more consistent results. Large longitudinal studies, stratified by age and gender, may also improve the expected outcomes. Regarding the results interpretation, the non-linear methods could be employed for assessment of individual variations. Special emphasis should be placed upon understanding of the "neural interference" phenomenon, and on explaining the possible neurofeedback modulation. The examination of the unexpected functional aspects and exploration of potential health prospects, will keep the society awake to potential alerts from these societal alarms, better known as mobile phones.

\section{REFERENCES}

Bachmann M, Lass J, Hinrikus H. Spectral asymmetry index and Higuchi's fractal dimension for detecting microwave radiation effect on electroencephalographic signal. Proc. Est. Acad. Sci. 2014; 63: 234.

COST Action BM0704: Emerging EMF Technologies and Health Risk Management. European Cooperation in the field of Scientific and Technical Research COST. 2007. Available on:

http://w3.cost.eu/fileadmin/domain_files/BMBS/Acti on_BM0704/mou/BM0704-e.pdf

Croft RJ, Hamblin DL, Spong J, Wood AW, McKenzie RJ, Stough C. The effect of mobile phone electromagnetic fields on the alpha rhythm of human electroencephalogram. Bioelectromagnetics 2008; 29: 1-10.

EU FP6 SAFE-EMF Project: Upgrading the research capacities for safety and health effects of human exposure to electromagnetic fields. 2009. Available on: http://cordis.europa.eu/documents/documentlibrary/1 25823131EN6.pdf.

Hinrikus H, Bachmann M, Lass J. Parametric mechanism of excitation of the electroencephalographic rhythms by modulated microwave radiation. Int. J. Radiat. Biol. 2011; 87: 1077-1085.

Hinrikus H, Bachmann M, Lass J, Karai D, Tuulik V. Effect of low frequency modulated microwave exposure on human EEG: individual sensitivity. Bioelectromagnetics. 2008a; 29: 527-538. 
Hinrikus H, Bachmann M, Lass J, Tomson R, Tuulik V. Effect of 7, 14 and $21 \mathrm{~Hz}$ modulated $450 \mathrm{MHz}$ microwave radiation on human electroencephalographic rhythms. Int. J. Radiat. Biol. 2008b. 84: 69-79.

Hinrikus H, Parts M, Lass J, Tuulik V. Changes in human EEG caused by low level modulated microwave stimulation. Bioelectromagnetics. 2004; 25: 431-440.

Hountala CD, Maganioti AE, Papageorgiou CC, Nanou ED, Kyprianou MA, Tsiafakis VG, Rabavilas AD, Capsalis CN. The spectral power coherence of the EEG under different EMF conditions. Neurosci. Lett. 2008; 441: 188-192.

Huber R, Treyer V, Borbély AA, Schuderer J, Gottselig JM, Landolt H-P, Werth E, Berthold T, Kuster N, Buck A, Achermann P. Electromagnetic fields, such as those from mobile phones, alter regional cerebral blood flow and sleep and waking EEG. J. Sleep Res. 2002; 11: 289-295.

Isa R, Pasya I, Taib M, Jahidin A, Omar W, Fuad N. Classification of Brainwave Asymmetry Influenced by Mobile Phone Radiofrequency Emission. Procedia - Soc. Behav. Sci. 2013; 97: 538-545.

Juutilainen J, Höytö A, Kumlin T, Naarala J. Review of possible modulation-dependent biological effects of radiofrequency fields. Bioelectromagnetics. 2011; 32: 511-534.

Kramarenko AV, Tan U. Effects of high-frequency electromagnetic fields on human EEG: a brain mapping study. Int. J. Neurosci. 2003; 113: 1007-1019.

Kwon MS, Hämäläinen H. Effects of mobile phone electromagnetic fields: critical evaluation of behavioral and neurophysiological studies. Bioelectromagnetics. 2011; 32: 253-272.

Loughran SP, Benz DC, Schmid MR, Murbach M, Kuster N, Achermann P. No increased sensitivity in brain activity of adolescents exposed to mobile phone-like emissions. Clin. Neurophysiol. Off. J. Int. Fed. Clin. Neurophysiol. 2013; 124: 1303-1308.

Marino AA, Carrubba S. The effects of mobile-phone electromagnetic fields on brain electrical activity: a critical analysis of the literature. Electromagn. Biol. Med. 2009; 28: 250-274.

Perentos N, Croft RJ, McKenzie RJ, Cosic I. The alpha band of the resting electroencephalogram under pulsed and continuous radio frequency exposures. IEEE Trans. Biomed. Eng. 2013; 60: 1702-1710.

Perentos N, Croft RJ, McKenzie RJ, Cvetkovic D, Cosic I. Comparison of the effects of continuous and pulsed mobile phone like RF exposure on the human EEG. Australas. Phys. Eng. Sci. Med. Support. Australas. Coll. Phys. Sci. Med. Australas. Assoc. Phys. Sci. Med. 2007; 30: 274-280.

Pop-Jordanova N, Pop-Jordanov J. Spectrum-weighted EEG frequency ("brain-rate") as a quantitative indicator of mental arousal. Pril. Makedon. Akad. Na Nauk. Umet. Oddelenie Za Biološki Med. Nauki Contrib. Maced. Acad. Sci. Arts Sect. Biol. Med. Sci. 2005; 26: 35-42.
Pop-Jordanov J, Pop-Jordanova N. Mobile Phones, E E G And Mental Activity. WebmedCentral Brain. 2011; 2:WMC001493.

Regel SJ, Gottselig JM, Schuderer J, Tinguely G, Rétey JV, Kuster N, Landolt H-P, Achermann P. Pulsed radio frequency radiation affects cognitive performance and the waking electroencephalogram. Neuroreport. 2007; 18: 803-807.

Van Rongen E, Croft R, Juutilainen J, Lagroye I, Miyakoshi J, Saunders R, de Seze R, Tenforde T, Verschaeve L, Veyret B, Xu Z. Effects of radiofrequency electromagnetic fields on the human nervous system. J. Toxicol. Environ. Health B Crit. Rev. 2009; 12: 572-597.

Suhhova A, Bachmann M, Karai D, Lass J, Hinrikus H. Effect of microwave radiation on human EEG at two different levels of exposure. Bioelectromagnetics 2013; 34: 264-274.

Valentini E, Curcio G, Moroni F, Ferrara M, De Gennaro L, Bertini M. Neurophysiological effects of mobile phone electromagnetic fields on humans: a comprehensive review. Bioelectromagnetics 2007; 28: 415432.

Vecchio F, Babiloni C, Ferreri F, Buffo P, Cibelli G, Curcio G, van Dijkman S, Melgari J-M, Giambattistelli F, Rossini PM. Mobile phone emission modulates interhemispheric functional coupling of EEG alpha rhythms in elderly compared to young subjects. Clin. Neurophysiol. Off. J. Int. Fed. Clin. Neurophysiol. 2010; 121: 163-171.

Vijayalaxmi, Scarfi MR. International and national expert group evaluations: biological/health effects of radiofrequency fields. Int. J. Environ. Res. Public. Health 2014; 11: 9376-9408.

\section{Резиме}

\section{МОЗОЧНА ТОПОГРАФИЈА \\ НА ЕМФ-ИНДУЦИРАНИ ЕЕГ-ЕФЕКТИ ВО БУДНО МИРУВАњЕ: МАПИРАЊЕ НА НАОДИ И ТАРГЕТИРАЊЕ НА ИДНИ ИЗГЛЕДИ}

\section{Билјана Ѓонеска', Силвана Марковска-Симоска ${ }^{1}$, Хиие Хинрикус², Нада Поп-Јорданова ${ }^{1}$, Јордан Поп-Јорданов ${ }^{1}$}

\footnotetext{
${ }^{1}$ Македонска академија на науките

и уметностите, Скопје, Р. Македонија

2 Технолошки универзитет, Талин, Естонија
}

Boвeg: Покривајќи период од неколку декади, но премостувајќи две ери, мобилните телефони ја означија зората на технолошката револуција како нејзин најистакнат симбол. При- 
тоа, паралелно со матурацијата на генерациите родени со раѓањето на мобилните телефони, зрее и потребата од научно базирана евалуација на здравствени ефекти од нив.

Цел: Изложениот преглед претставува обид да се покрие празниот од во полудеценискиот период на бројни истражувања и да се направи синтеза на кумулираното знаење за ЕМФ-индуцирани ЕЕГ-промени.

Материјал и ме togu: Направена е селекција од 28 публикации што го истражуваат ефектот на мобилните телефони врз хумана ЕЕГ-активност при будно мирување за период од две децении, на регион од три континенти и 12 држави, од кои 75\% имаат позитивни наоди.

Заклучоци: Вообичаен протокол на типичната студија вклучува испитување на помали примероци (10-30 испитаници) од возрасна популација (20-60 година), со краткорочна експозиција на GSM пулсно-модулиран сигнал (10-30 минути). Процената најчесто се базира на линеарни методи за квантитативна анализа, додека евидентираните промени вклучуваат постериорно покачување на мозочна активност во алфа и бета фреквентен опсег. Сепак, квалитативните варијации остануваат отворени за интерпретација. Во иднина, мултипликација на супспецифични студии со строги протоколи би водела кон конзистентна интерпретација на резултатите. Лонгитудинални и интернационални епидемиолошки студии, стратифицирани според пол и возраст, би придонеле за подобро предвидување на наодите. Нелинеарни методи за анализа би биле од корист за процена на индивидуални варијации во наодите. Акцентот треба да биде ставен на теории/методи за подобро разбирање на суптилната интеракција меѓу радијационите карактеристики на мобилните телефони и спектралните карактеристики на мозочната активност од човекот.

Клучни зборови: мобилни телефони, електромагнетно зрачење, хуман електроенцефалограм, будност, мирување 